\title{
The Treatment Outcomes of Medullary Thyroid Carcinoma
}

\author{
Yoon Jung Choi ${ }^{1}$, Dae Hyoung Kang ${ }^{1}$, Jong Chul Hong ${ }^{2}$, \\ Hyoung Shin Lee ${ }^{1}$, Sung Won Kim ${ }^{1}$ and Kang Dae Lee ${ }^{1}$ \\ ${ }^{I}$ Department of Otolaryngology-Head and Neck Surgery, Kosin University College of Medicine, Busan; and \\ ${ }^{2}$ Department of Otolaryngology-Head and Neck Surgery, Dong-A University College of Medicine, Busan, Korea
}

\section{갑상선 수질암의 치료 결과}

최윤정 ${ }^{1} \cdot$ 강대형 $^{1} \cdot$ 홍종철 $^{2} \cdot$ 이형신 $^{1} \cdot$ 김성원 $^{1} \cdot$ 이강대 $^{1}$

고신대학교 의과대학 이비인후과학교실, ${ }^{1}$ 동아대학교 의과대학 이비인후과학교실 ${ }^{2}$

Received December 23, 2011

Revised February 16, 2012

Accepted February 21, 2012

Address for correspondence

Kang Dae Lee, MD

Department of Otolaryngology-

Head and Neck Surgery,

Kosin University

College of Medicine,

262 Gamcheon-ro, Seo-gu,

Busan 602-702, Korea

Tel $+82-51-990-6248$

Fax +82-51-245-8539

E-mail kosinent@yahoo.co.kr
Background and Objectives The aim of this study was to evaluate the treatment outcomes of medullary thyroid carcinoma (MTC) by retrospective data analysis.

Subjects and Method We conducted a retrospective chart review of 17 cases of pathologically proven MTC patients who were treated from 1998 to 2010 at the department of Otolaryngology-Head and Neck Surgery, Kosin University College of Medicine.

Results The mean tumor size was $2.32 \mathrm{~cm}(0.5-3.4 \mathrm{~cm})$. Seventy-one percent of patients were diagnosed with advanced stage (III or IV) of MTC. We performed RET genetic screening in 8 of 17 patients. Hereditary MTC was found in 3 of 17 patients $(18 \%)$ and sporadic MTC was found in 14 of 17 (82\%). The preoperative assessment of basal serum calcitonin (CT) level was performed in 15 of 17 patents. Eleven patients had elevated basal calcitonin levels ( $>13 \mathrm{pg} /$ $\mathrm{mL}$ ). After the operation for MTC, the serum CT levels were elevated in 7 patients. Overall 5-year survival rate was $94 \%$. Normalization of serum calcitonin level was accomplished more frequently in the absence of extra thyroidal invasion $(p=0.034)$, multifocal tumor $(p=0.02)$.

Conclusion The initial treatment of MTC is total thyroidectomy with central compartment neck dissection with or without lateral neck dissection. To detect recurrence or metastasis, regular checking of serum calcitonin is necessary. A better knowledge of prognostic factors could improve the management of MTC patients.

Korean J Otorhinolaryngol-Head Neck Surg 2012;55:166-72

Key Words Medullary thyroid carcinoma $\cdot$ Treatment.

\section{서 론}

영상기술의 발달과 치료 경험의 축적으로 분화성 갑상선암 에 대한 진단 및 치료방법은 많은 임상의에게 널리 이해되어 임 상적 적용이 되고 있는 반면에, 갑상선 수질암(medullary thyroid carcinoma, MTC)은 잘 알려져 있지 않다. 현재까지 갑상 선 수질암에 대한 임상경험을 가진 임상의가 그리 많지 않을 뿐더러 전향적인 임상연구도 분화성 갑상선암과 비교하여 많 이 부족한 실정이다. 갑상선 수질암은 전체 갑상선암의 약 5
$10 \%$ 를 차지하며, 다른 갑상선 유두상암이나 여포상암과는 달 리 칼시토닌(calcitonin)을 분비하는 갑상선 여포곁세포(parafollicular cell) 혹은 C-세포(C-cell)에서 기원하는 종양이기 때 문에 분화성 갑상선암과는 확실하게 구분되는 생화학적, 유전 적, 임상적인 특징을 가진다. ${ }^{1)}$ 갑상선 수질암은 유전자 돌연변이 를 동반 유무로 산발형(sporadic form)과 유전형(hereditary form)으로 구분하며, 가족형 수질암은 RET 유전자의 돌연변이 에 의해 발생하며, multiple endocrine neoplasm 2A(MEN 2A, Sipple's disease), MEN 2B, familial medullary thyroid carci- 
noma로 분류되고 다른 다양한 내분비질환과 동반되어 나타 난다. 수질암의 예후는 분화성 갑상선암보다는 나쁘고 역형성 암보다는 좋아 10년 생존율이 65\% 정도이며, 가족성 갑상선 수 질암은 비교적 나쁜 예후와 관련이 있는 것으로 알려져 있다. 수질암은 분화암과는 달리 방사성요오드 치료에 반응하지 않 으므로, 종양이 재발하거나 원격전이가 동반된 경우 외과적 절 제술 이외 다른 치료법이 없는 실정이다. ${ }^{2)}$

현재까지 국내 갑상선 수질암의 임상양상과 예후에 대한 보 고는 드물다. 이에 본 연구에서는 단일 의료기관의 후향적인 자 료 분석으로 갑상선 수질암으로 수술받은 환자들의 임상적 특 성을 살펴보고, 수술 후 결과를 고찰함으로써 예후에 대하여 알아보고자 하였다.

\section{대상 및 방법}

\section{대 상}

1998년부터 2010년까지 병원 이비인후과에서 갑상선 절제술 을 시행 받은 환자 중 술 후 병리 결과가 갑상선 수질암종으로 진단받은 환자 17 명의 의무 기록과 조직병리기록을 후향적으 로 분석하였다. 남녀비는 $7: 10$ 이고, 연령 분포는 24 세부터 74 세까지로 평균연령은 47.7세이며 평균 추적관찰 기간은 53개 월(8 134개월)이었다. 술 후 병리학적 소견상 갑상선 수질암에 합당하며, 술 전 종양인자인 혈청 칼시토닌의 기저치 또는 칼 슘 자극치가 $13 \mathrm{pg} / \mathrm{mL}$ 이상으로 상승되어 있는 경우 갑상선 수질암으로 정의하였다. 현미경 소견만으로 수질암의 진단이 애 매한 경우 chromogranin A 등에 대한 면역조직화학염색을 추 가로 시행하여 양성을 보이는 경우 수질암으로 판단하였다.

\section{방 법}

임상분석을 위하여 환자의 연령 및 성별, 수술 방법, 경부 림 프절 전이, 술 후 병리결과(크기, 다발성, 양측성, 피막외 침습) 와 추적 관찰기간 동안의 경부 재발 여부, 수술 전, 후 칼시토 닌의 농도를 조사하였다. 술 후 칼시토닌의 측정은 대개 수술 후 5 7일째에 측정하여 $13 \mathrm{pg} / \mathrm{mL}$ 이하의 수치를 보인 경우 정 상화 된 것으로, 수술 후 6 개월 이상 혹은 최종 경과 관찰 중 에서 측정된 수치 중 이보다 높은 수치가 있는 경우는 잔존암 이 있거나 전이가 있는 것으로 판단하였다. 유전성 갑상선 수 질암 여부를 확인하기 위해 RET 원종양 유전자 점돌연변이 검 사를 확인하였으며, 환자의 진단 당시 연령이 40세 미만이거나 병력청취 결과 가족력 및 과거력에서 MEN과의 연관성이 의 심될 경우 24시간 뇨에서 바닐린만델산(vanillylmandelic acid), 메타네프린(metanephrine)을 측정하였고, ${ }^{123}$ I-meta-iodobenzylguanidine scintigraphy, 부갑상선 호르몬 검사, 컴퓨터 전
산화단층촬영을 시행하였다. 수술 후 기저 혈청 칼시토닌 농도 가 지속적으로 상승되어 있거나, 정상화되었다 다시 상승한 경 우, 또는 신체검진, 경부초음파, 흥부 컴퓨터단층촬영 또는 양 전자 방출 컴퓨터단층촬영 등을 통하여 원격전이와 재발이 의 심되는 경우에는 경부 청소술을 시행해 조직학적으로 확진된 경 우에 재발로 판정 하였다. 다발성 병변은 조직학적으로 일측엽 에 둘 이상의 수질상 암종이 발견된 경우로 정의하였고, 양측 성 병변은 조직학적으로 양측엽에 동시에 수질암종이 발견된 것으로 정의하였다.

\section{통계학적 분석}

통계 분석은 SPSS version 18.0 for Windows(SPSS, Chicago, IL, USA) program을 이용하였다. 임상상에 관한 자료 는 Chi-square test, t-test를 사용하여 분석하였고, 범주형 변 수의 분석에서는 Chi-square test를, 연속형 변수에서는 t-test 를 사용하였다. 모든 검정에서 유의 수준은 $p$ value $<0.05$ 의 수 준에서 평가하였다.

\section{결 과}

\section{환자 진단 및 임상적 특징}

갑상선 수질암으로 진단하게 된 과정을 조사해 본 결과 총 17 예 중 9예(53\%)는 경부 종괴를 주증상으로 내원하였고, 7예(41\%) 는 뚜렷한 증상 없이 건강검진에서 시행한 경부 초음파상 우연 히 갑상선 결절이 발견되거나 혈청 칼시토닌 농도가 증가하여 초음파를 시행하던 중 수질암이 발견되었다. 간헐적인 고혈압 상승으로 갈색세포종이 의심되는 환자에서 수질암의 선별검사 를 통해 발견된 경우가 1예(6\%)였다.

대상 환자 17예 중 15 예에서 수술 전 미세침흡인세포검사를 시행하였다. 10예(66\%)에서 갑상선 수질암이 의심되었으며, 갑 상선 유두암을 포함하는 다른 악성종양이 의심되었던 경우가 3 예(20\%), 양성소견을 보였던 경우가 1예(7\%), 여포성 종양을 포함한 미결정형(indeterminate)으로 나타났던 경우가 1예(7\%) 였다. 대상 환자들의 임상적 특성을 환자수와 통계적인 유의성 을 고려하지 않고 산발형 수질암과 유전형 수질암으로 구분하 여 비교하였을 때 유전형이 산발형보다 진단 당시 평균연령이 더 어린 것으로 나타났고, 종양이 더 흔하게 양엽에 발생하였다 (Table 1). 유전형의 3예 중 2예에서 수질암이 양측성으로 발 생하였고 이 중 1 예에서는 갈색세포종과 부갑상선과증식증을 동반하고 있었다. 유전형 수질암의 나머지 1 예에서는 결절이 양 측성으로 있었으나 조직검사상 일측에서만 갑상선 수질암으로 진단되었다.

수술 전 혈청 칼시토닌 농도를 측정한 15 예에서 칼시토닌 농 
Table 1. Clinicopathologic features of medullary thyroid carcinoma patients

\begin{tabular}{lcc}
\hline \multicolumn{1}{c}{ Factors } & Sporadic MTC $(\mathrm{n}=14)$ & Hereditary MTC $(\mathrm{n}=3)$ \\
\hline Sex $(\mathrm{M}: \mathrm{F})$ & $6: 8$ & $1: 2$ \\
Age (years) & $50.4 \pm 19.5$ & $40.6 \pm 14.6$ \\
Tumor size $(\mathrm{cm})$ & $1.84 \pm 0.87$ & $2.8 \pm 0.99$ \\
$<2 \mathrm{~cm}(\%)$ & $54(7 / 13)$ & $33(1 / 3)$ \\
$\geq 2 \mathrm{~cm}(\%)$ & $46(6 / 13)$ & $67(2 / 3)$ \\
ETE (\%) & $46(6 / 13)$ & $67(2 / 3)$ \\
Bilateral or multifocality (\%) & $0(0 / 13)$ & $67(2 / 3)$ \\
Lymph node metastasis (\%) & $61(8 / 13)$ & $67(2 / 3)$ \\
Preop calcitonin $(\mathrm{pg} / \mathrm{mL})$ & $510.3 \pm 482.4(12 / 14)$ & $1105 \pm 154.9(3 / 3)$ \\
Postop calcitonin $(\mathrm{pg} / \mathrm{mL})$ & $315.7 \pm 588$ & $135 \pm 197$ \\
Follow-up (months) & $42.5 \pm 39$ & $94 \pm 17.3$ \\
\hline
\end{tabular}

Values are expressed as mean \pm standard deviation. ETE: extrathyroidal extension, MTC: medullary thyroid carcinoma, Preop: preoperative, Postop: postoperative

도를 조사한 결과, 11 예에서 수술 전 칼시토닌 농도가 $13 \mathrm{pg} / \mathrm{mL}$ 이상으로 증가되어 있었다. 수술 전 혈청 칼시토닌 농도가 증가 할수록 종양의 크기도 증가하는 경향을 보였으나 통계적으 로 유의하지는 않았다.

\section{술 후 병리 결과}

현미경 소견만으로 수질암의 진단이 애매하여 congored, chromogranin A 등에 대한 면역조직화학염색을 추가로 시행한 경우는 13예였다. 이 가운데 congored에 염색된 경우는 2예 (15\%), chromogranin A에 염색된 경우는 10예(77\%)였고, 염 색이 안된 경우는 1 예(8\%)였다.

\section{$\mathrm{RET}$ 원종양 유전자 점돌연변이 검사 결과}

$\mathrm{RET}$ 유전자 점돌연변이 검사를 17 예 중 8 예에서 시행하였 다. 1 예는 MEN 2A 환자였고, 2예는 가족성 갑상선 수질암, 나 머지 5예는 산발형 갑상선 수질암이었다. 1 명의 MEN 2A 환자 에서는 11번 엑손(exon)의 643번 코돈(codon)의 C643W(TGC to TGG, cysteine to tryptophan)로 변이가 있었다. 2예의 가 족형 갑상선 수질암 환자는 모녀관계이고, 10 번 엑손(exon)의 618번 코돈(codon)의 C618R(TGC to CGC, cysteine to arginine)로 변이가 있었다. 그리고 그 가족들의 구성원 9명 중 4명 (조모, 친모, 삼촌, 삼촌의 딸)에서 지표 환자와 같은 RET 유 전자 점돌연변이를 발견하였고, 나머지 가족 구성원들은 $\mathrm{MEN}$ 을 동반하지 않아 가족형 갑상선 수질암으로 확진하였다. 5 예 의 산발형 갑상선 수질암 환자에서는 점돌연변이가 발견되지 않았다.

\section{수술적 치료방법}

갑상선 수질암에 대한 일차적인 수술 방법으로 갑상선에 대 해서는 모두 갑상선 전절제술(total thyroidectomy)를 시행하
였다. 림프절 절제는 중심구역 림프절 절제술을 7명 시행하였 고, 중심구역 림프절 절제술과 함께 동측 경부림프절 청소술을 시행한 환자 6 명, 양측 경부 림프절 청소술을 시행한 환자가 2 명이었다. 중심구역 림프절 절제술과 동측 경부림프절 청소술 및 상종격동림프절 절제술이 1 예에서 시행되었고, 중심구역 림 프절 절제술과 양측 경부림프절 청소술 및 상종격동림프절 절 제술이 1 예 있었다. 또한 이 중 1 예에서는 후인두림프절에 전이 가 있어 측경부 림프절 절제술시에 후인두림프절도 같이 절제 하였다. 측경부 림프절 절제는 주로 측경부의 림프절이 촉지되 거나 초음파 또는 컴퓨터단층촬영 및 미세침세포흡인검사상 측경부의 갑상선 수질암의 전이가 의심되거나 전이로 확진된 경 우 주로 시행하였다.

\section{경부림프절 전이 양상}

전체 17 명 중 10 명에서 병리학적으로 림프절 전이가 확인되 었으며, 그 중 1예(10\%)는 중심부에만, 6예(60\%)는 측경부에만 림프절 전이가 국한되었다. 3 예(30\%)에서는 중심부와 측경부 로 동시에 전이를, 그 중 1예(10\%)는 중심부와 측경부, 인후두 림프절에, 2(20\%)예에서는 종격동 림프절에 전이가 확인되었 다. 경부 림프절 전이는 크기가 커질수록 증가하였으나 통계적 으로 유의하지는 않았다 $(p=0.59)$.

\section{수술 후 결과 및 합병증}

평균 53개월간(8 134개월)의 추적관찰 기간 동안 대상 환자 17 예 중 사망한 예는 1 예가 있었으며, 5 년 생존율은 $94 \%$ 였 다. 4예에서 경부 림프절 재발이 있었는데, 첫 치료 후 재발까 지 평균 시간은 34 개월이었다. 이 중 1 예에서는 경부청소술 후 3 회 이상의 국소림프절 재발과 폐와 골의 원격전이 소견이 있 는 상태로, 환자의 자의로 보존적 치료로 경과 관찰 중이며, 3 예는 경부청소술 후 영상학적으로 재발소견이나 전이소견은 보 
이지 않았으나 술 후 혈청 고칼시토닌이 측정되어 잠재성 전이 상태로 경과 관찰 중이다. 합병증으로는 일측의 반회후두신경 손상이 1예, 일시적인 부갑상선 기능저하증이 2예 있었고, 어깨 운동장애가 1예의 환자에서 발생하였으나 재활 치료 후 호전되 었다.

술 후 영상학적인 완치는 94\%(16/17) 있었고, 생화학적인 완 치(calcitonin $13 \mathrm{pg} / \mathrm{mL}$ 미만)는 47\%(7/15)였다.

\section{술 후 칼시토닌 정상화와 관련된 예후 인자 분석}

산발형과 유전형 수질암 간의 수술 후 칼시토닌 정상화에 관 여하는 인자와 생존예측 인자를 알아보고자 하였으나, 환자수 가 적어 두 그룹을 합하여 분석하였다(Table 2). 수술 후 최종 혈청 칼시토닌 농도의 중간값은 $282 \mathrm{pg} / \mathrm{mL}$ 였다. 수술 전 혈 청 칼시토닌 농도가 증가되었던 11예 중 4예(31\%)는 수술 후 6 개월 이내에 칼시토닌 농도가 $13 \mathrm{pg} / \mathrm{mL}$ 미만으로 감소하였 고, 수술 후 1 년 이내로 다소 경과 관찰 기관이 짧았던 환자 중 에 마지막 칼시토닌 농도가 $20 \mathrm{pg} / \mathrm{mL}$ 미만이 3예(마지막 칼시 토닌 농도 $17.56,19.25,17.1 \mathrm{pg} / \mathrm{mL}$ )로 이들은 점차 감소하는 경향으로 보아 추후 칼시토닌 재검사시에 정상화되었을 것으 로 추정되어 통계분석에 포함하였다.

이 중 이들의 수술 전 혈청 칼시토닌 농도의 중간값은 466 $\mathrm{pg} / \mathrm{mL}$ 였다. 수술 전 정상 칼시토닌 농도를 보인 2예는 종양

Table 2. Risk factors for the normalization of calcitonin after surgery

\begin{tabular}{|c|c|c|c|}
\hline Factors & Normalized & Not & $p$ value \\
\hline Sex & & & 0.48 \\
\hline Female & 5 & 3 & \\
\hline Male & 5 & 2 & \\
\hline Age (years) & & & 0.361 \\
\hline$<45$ & 3 & 2 & \\
\hline$\geq 45$ & 6 & 4 & \\
\hline Tumor size $(\mathrm{cm})$ & & & 0.059 \\
\hline$<2$ & 6 & 1 & \\
\hline$\geq 2$ & 5 & 1 & \\
\hline ETE & & & 0.034 \\
\hline Negative & 7 & 1 & \\
\hline Positive & 3 & 4 & \\
\hline Bilateral or multifocality & & & 0.02 \\
\hline Negative & 3 & 1 & \\
\hline Positive & 8 & 1 & \\
\hline Lymph node metastasis & & & 0.059 \\
\hline Negative & 6 & 0 & \\
\hline Positive & 4 & 5 & \\
\hline Preop calcitonin (pg/mL) & & & 0.317 \\
\hline Negative $(<500 \mathrm{pg} / \mathrm{mL})$ & 3 & 0 & \\
\hline Positive (>500 pg/mL) & 6 & 3 & \\
\hline
\end{tabular}

ETE: extrathyroidal extension, Preop: preoperative
의 크기가 $2 \mathrm{~cm}$ 이하로 한쪽 엽에 국한되어 있었고, 갑상선외 조직이나 림프절 전이는 발견되지 않았다. 이들 모두 53개월 동 안의 추적 관찰기간 동안 국소재발이나 원격전이는 발견되지 않았다.

술 후 예후인자로서 성별, 연령(45세 기준), 수술 전 칼시토닌 치( $>500 \mathrm{pg} / \mathrm{mL}$ 기준), 종양의 크기 $(2 \mathrm{~cm}$ 기준), 종양의 갑상선 외 침윤여부, 다발성 혹은 양측성 여부, 림프절 전이 여부에 대 하여 수술 후 칼시토닌 정상화에 미치는 영향을 단변량 분석 하였을 때 갑상선의 조직침윤이 없을수록 $(p=0.034)$, 다발성 혹 은 양측성이 아닐수록 $(p=0.02)$ 통계학적으로 유의하게 수술 후 칼시토닌 정상화의 빈도가 높음을 알 수 있었다(Table 2). $\mathrm{MEN}$ 과의 연관성을 알아보고자 하였으나 MEN 2A 환자가 1 예 밖에 없어 제외하였다. 다변랑 분석은 통계적 유의성을 관 찰하기에는 대상환자의 수가 너무 적어 시행하지 못하였다.

수술 후 혈청 칼시토닌 농도가 정상화되었던 7명의 환자 추 적관찰기간 동안 국소 재발 또는 원격전이가 발생한 경우는 1 예도 없었다.

\section{고 찰}

본 연구에서는 전체 갑상선암의 3 10\%를 차지하는 매우 드 문 종양인 갑상선 수질암의 임상적 특성을 산발형과 유전형으 로 나누어 살펴보고 치료 결과와 예후에 관련되는 인자들을 살 펴보고자 하였으나 환자수가 적어 두군 간의 비교가 곤란하였 던 아쉬운 점이 있다. 유전형 수질암은 갈색세포종과 부갑상선 과증식증과 동반되는 MEN 2A, 갈색세포종, 거대결장 그리고 점막 신경종과 같은 특징적인 외향을 보이는 $\mathrm{MEN} 2 \mathrm{~B}$, 다른 부 위의 질환 없이 갑상선 수질암만 발생하는 가족성 수질암 세가 지로 분류할 수 있다. 이 가운데 MEN 2A가 가장 흔한 형태로 전체 유전형 수질암의 약 65 75\%를 차지하며, 대부분 35세 이 전에 진단되며 남녀 간에 발생 빈도의 차이는 없는 것으로 알 려져 있다. ${ }^{3)}$ 이에 비해 산발형은 주로 50 60대에 발생하고 보 통 단발성이며 편측에 발생하고 예후도 유전형보다 나쁘다. 본 연구에서는 유전형 수질암 환자가 17\%(3/17)를 차지하여 기존에 알려진 바와 차이를 보이지 않았으나, 대상 환자가 적어 추후 보다 많은 수의 환자를 대상으로 한 연구가 필요할 것으 로 사료된다. 통계적인 유의성은 없었지만, 산발형 수질암 환자 에서 진단 당시 또는 경과 관찰 도중 원격 전이를 동반한 환자 가 더 많은 것으로 나타나 유전형 수질암에 비하여 더 공격적인 양상을 띄는 것으로 나타났다. 또한 수술 후 종양 표지자인 혈 청 칼시토닌이 여전히 증가되어 있는 환자의 비율이 산발형 수질암 환자에서 더 높고, 추적관찰기간 동안 국소 재발한 4 명 의 환자 모두 산발형 수질암 환자로 나타나 산발형 수질암이 
유전형 수질암보다 나쁜 예후를 나타내는 성향을 보였다.

유전형 갑상선 수질암은 염색체 10q11.2에 위치하는 RET 원종양 유전자의 배선 돌연변이(germ-line mutation)에 의해 생 긴다. RET 유전자는 티록신 인산화 효소 수용체(tyrosine kinase receptor)를 발현하는 21 액손 유전자이다. 이 수용체는 세 포외 도메인(extracellular domain)의 카데린 유사 부위(cadherin-like region), 막외측의 시스테인 풍부 부위(cysteine-rich region), 세포내 티록신 인산화 효손 도메인(intracellular tyrosin kinase domain)으로 구성되어 있다. RET 유전자는 1993 년 처음 소개되었고, 현재는 유전형 갑상선 수질암의 $95 \%$ 이 상에서 발견된다고 알려져 있으며, MEN 2의 $98 \%$ 는 exon 5 , $8,10,11,13,14,15,16$ 에 점돌연변이를 가지고 있다. ${ }^{5)} \mathrm{MEN}$ $2 \mathrm{~A}$ 의 돌연변이는 대부분 cysteine-rich extracellular domain 에서 발생하고, exon 10 의 codons $609,611,618,620$ 에서 cysteine이 다른 아미노산으로 변경되며, 그 중 codon 634에서 cysteine이 arginine으로 치환되는 경우(50\%)가 가장 흔하다 (TGC to CGC). MEN 2B의 95\%는 exon 16의 codon 918에서 methionine이 threonine으로 치환되는 경우이다. ${ }^{5)} \mathrm{RET} \mathrm{mu-}$ tation-positive인 환자는 크롬친화세포종을 선별하기 위해 매 년 혈청 또는 24시간 소변검사에서 metanephrines, normetanephrine 검사를 시행한다. 선별검사는 $\mathrm{MEN} 2 \mathrm{~B}$ 와 codon 630, 634 연관 RET mutation 보유자는 8세부터, 그 외 MEN 2A RET mutation 보유자는 20세부터 시작한다. 선별검사는 매년 혈청 또는 24시간 소변검사에서 metanephrines, normetanephrine 검사를 시작한다. 가족형 수질암 관련 RET mutation 이 있는 환자는 20 세부터 주기적으로 선별검사가 필요하다.

갑상선 수질암은 결절의 미세침흡인세포검사로 진단할 수 있 다. 본 연구에서 수술 전 미세침흡인세포검사를 시행한 16 예 중 10 예에서 수질암으로 진단받아 약 $63 \%$ 의 민감도를 보였다. 특 징적으로 stromal amyloid를 관찰할 수 있지만, 갑상선 여포 는 관찰되지 않는다. 더불어 유전형 갑상선 수질암에서 보이는 $\mathrm{C}$-세포 증식증은 수질암의 전구 병변으로 여겨지기 때문에 참 고하여야 한다. 갑상선 수질암에서 혈청 칼시토닌이 증가하기 때문에 이를 측정하여 진단할 수도 있고 경과 관찰 중에 재발 여부 판정에도 도움이 되기 때문에 칼시토닌은 수질암의 중요 한 종양 표지자이다. ${ }^{6)}$ 기저 혈청 칼시토닌 농도가 $100 \mathrm{pg} / \mathrm{mL}$ 이상이면 갑상선 수질암의 가능성은 높다. 또한 수술 전 칼시 토닌의 상승 정도는 암의 크기와 관련이 있으며, 림프절 전이 가 있을 때는 칼시토닌이 $10 \sim 40 \mathrm{pg} / \mathrm{mL}$, 원격전이가 있으면 150 $\mathrm{pg} / \mathrm{mL}$ 이상으로 상승한다. ${ }^{7)}$ 갑상선 수질암에서는 혈중 칼시토 닌이 증가하지 않는 경우가 보고된 바 있는데, 그 원인으로는 종양의 분화도가 나빠 칼시토닌을 생성하지 못하는 경우와, 칼시토닌을 생성할 수 있는 능력은 있으나 혈중으로 분비하는
단계에 이상이 있을 가능성이 제기되었다. ${ }^{6}$ 본 연구에서는 17 예 중 2예에서 술 전 칼시토닌이 증가하지 않았다.

영상학적으로는 새로 진단된 수질암 환자에서 경부초음파 를 시행하여 다발성 결절 여부와 국소 림프절 전이 여부를 확 인하여야 한다. 또한 흥부와 복부의 컴퓨터 전산화단층촬영 검 사를 하여 원격전이가 있는지, 다른 동반된 질환이 있는지 확 인하여야 한다. 컴퓨터 전산화단층촬영 등 영상검사의 특징은 석회화 음영으로 전체 환자의 약 $1 / 2$ 에서 나타난다. 본 연구 2 예의 환자에서 알 수 있듯이, 종격동 림프절로 전이가 있을 수 있기 때문에 흥부단순촬영이나 컴퓨터 전산화단층촬영에서 종격동 확대의 소견을 확인해야 한다.

치료 방법으로는 수질암 환자를 수술하기 전에 모든 환자 의 병기를 정확히 하여야 하며, 부갑상선 기능항진증이나 크롬 친화세포종의 동반유무 및 유전형 수질암 여부를 알아보아야 한다. 임상적으로 확실한 갑상선 수질암을 가진 환자에서 가장 좋은 수술법은 최소한 갑상선 전절제술과 중심경부 림프절 청 소술이다. 산발형 수질암이라도 $20 \%$ 의 환자에서 다초점성 $(\mathrm{mu}-$ ltifocal), 양측성(bilaterally)을 보이고 선내림프절전이(intraglandular lymphatic spread)가 발생할 수 있기 때문에 갑상 선 전절제술을 하는 것이 추천된다. 또한 유전형 수질암의 임 상적 특징이 없는 경우(양측성 병변 또는 수질암 가족력)에도 추후에 시행한 RET 유전자 돌연변이 검사에서 $\mathrm{MEN}$ 으로 진 단되는 경우가 16 19\%이기 때문에 수질암의 효과적인 치료로 갑상선 전절제술을 시행한다. ${ }^{8}$

종양의 크기에 따라 림프절 전이의 빈도를 보면 $1 \mathrm{~cm}$ 보다 작은 직경을 가지는 수질암의 경우 20 30\%, 1 4 cm는 50\%, $4 \mathrm{~cm}$ 이상 또는 $\mathrm{T} 4 \mathrm{a}$ 이상인 경우는 $90 \%$ 이상에서 림프절 전 이를 보인다. ${ }^{9,10}$ 한편으로는, 일측성 수질암의 경우 $1 \mathrm{~cm}$ 보다 작은 경우에도 반대측 측경부 림프절 전이가 $20 \%$ 의 빈도로 발생한다. 하지만 반대측 측경부 전이는 중심경부 림프절 전 이가 있거나 동측 측경부 림프절 전이가 있는 환자에서만 발 생하는 특징을 가진다. 그래서 중심경부 림프절이나 동측 측 경부 전이가 없는 일측성 갑상선 수질암 환자에서 반대측 측경 부 림프절 절제술은 하지 않는다. 그리고 중심경부 림프절 전이 가 있는 경우에 상부종격동 림프절 절제술도 시행한다. ${ }^{10,11}$ 림 프절 절제술은 주변 구조물의 침범이 없는 경우에는 척수부신 경, 흥쇄유돌근, 내경정맥 등을 보존하면서 수술한다.

수질암의 경우 방사선 요오드치료와 같은 보조적 치료가 효과가 없어 보존적 치료방침은 적절한 방법이 아니다. 따라서 일차적 치료의 실패는 종양의 재발을 의미하므로 일차적 수술 적 절제가 완치를 위한 유일한 기회라고 볼 수 있다.

잔존암이나 재발암을 알아보는 데 칼시토닌 수치가 도움이 된다. 만약 술 후 칼시토닌 수치가 증가한다면 수술적 확인에 
앞서 전이여부에 대한 조사를 해야 한다. 그리고 경부에 대한 재수술은 많은 위험을 감수해야 하기 때문에, 확실한 수술적 이 점이 있는 경우에만 재수술을 시행하여야 한다. 처음 수술에 서 부적절한 수술을 받았거나 국소 침윤이 의심되면 수술적 제 거를 시도하는데, 특히 기도 또는 종격동을 침범하면 기도 증 상을 유발할 수 있으므로 수술로 제거하여야 한다. 진행된 국 소병변이나 원격전이가 있다면 국소 및 경부 병변을 제거하되 언어, 연하 및 부갑상선 기능을 보존하기 위해 덜 공격적인 수 술이 적절할 수 있다. 국소 재발암이 수술로 완전 제거가 어려 워 외부 방사선 치료를 해야하더라도, 증상을 유발한다면 방 사선 치료를 하기 전에 수술적 제거를 고려해야 한다. ${ }^{12,13)}$

수질암에서 원격전이는 가장 흔한 사망원인으로 초기 진단 당시에 $50 \%$ 정도는 원격전이가 있다. 간, 폐, 뼈 등의 장기에 전 이가 있는 경우가 흔하다. 본 연구에서는 1 예에서 폐와 뼈에 원격전이가 있었다.

수질암의 예후는 분화성 갑상선암보다는 나쁘고 역형성 갑 상선암보다는 좋아 10 년 생존율이 약 $65 \%$ 이며, 가족 검진을 통해 초기 병기에 발견하여 치료를 시행한 경우에는 약 $90 \%$ 이 다. 림프절 전이 없이 갑상선 내에 국한되어 있다면 재발률도 낮 고 사망도 거의 하지 않는다. 하지만 갑상선 수질암의 대부분은 진단 당시에 림프절 전이가 동반되어 있고, 이런 경우는 재발 을 잘하는 경향이 있다. 그래서 술 후 경과관찰이 중요하다. ${ }^{2)}$

술 후 2 3개월에 칼시토닌이 확인되지 않는다면 이는 완치 의 증거이고, 다른 검사는 필요하지 않다, 그리고 2 3년간 6개 월 간격으로, 그 이후에는 매년 한 번씩 칼시토닌 수치를 확인 하면 된다. 이런 경우 장기추적 관찰을 해보면 $3 \%$ 정도에서만 재발을 한다. ${ }^{14)}$ 반면에 술 후 2 3개월에 칼시토닌이 확인되면 완치가 되지 않았다고 보는데, 칼시토닌 수치가 $150 \mathrm{pg} / \mathrm{mL}$ 이 상이 되기 전까지 영상 검사에서는 병변이 쉽게 확인되지 않고, ${ }^{15)}$ 칼시토닌이 $150 \mathrm{pg} / \mathrm{mL}$ 이하에서는 대부분 국소 질환과 관련 이 있기 때문에 경부 초음파로 주의 깊게 확인하여야 한다. ${ }^{12)}$ 칼시토닌이 $150 \mathrm{pg} / \mathrm{mL}$ 이상이라면 기본 검사는 유사하지만 원격전이가 있는지를 반드시 확인해 보아야 한다. 기저 칼시토 닌 수치가 $1000 \mathrm{pg} / \mathrm{mL}$ 이상이고 경부 및 상부 종격동에 이상 이 없는 경우에는 원격전이의 가능성을 고려하여야 하는데, 간 에 전이되는 경우가 가장 흔하다. 칼시토닌은 양성인데 잔존 또 는 재발 병변이 확인되지 않는다면 매 6개월마다 칼시토닌과 발암배아성항원(CEA)의 배가시간(doubling time)을 평가하면 서 장기 추적 관찰하는 것이 중요하다. 이는 질병이 진행하는 것 과 연관이 있고 생존율과 관련이 있기 때문이다. ${ }^{14,16)}$

본 연구 결과 45\%(5/11)의 환자에서 수술 후 혈청 칼시토닌 농도가 지속적으로 상승되어 있는 것으로 나타나, 수술 후 생 화학적 완치에 이르지 못하는 비율을 38 57\%로 보고하고 있
는 기존 연구들과 ${ }^{17,18)}$ 유사한 결과를 보였다. 또한 수술 후 칼시 토닌 정상화에 미치는 영향을 단별량 분석하였을 때 갑상선외 조직침윤이 없을수록, 다발성 혹은 양측성이 아닐수록 통계학 적으로 유의하게 수술 후 칼시토닌 정상화의 빈도가 높음을 알 수 있었다.

지금까지 연구결과 수술 후 혈청 칼시토닌의 정상화와 관련 된 인자로 젊은 연령, 여자, 조기병기, 작은 종양의 크기 등이 보 고되고 있으며 ${ }^{18)}$ 이 가운데 가장 중요한 요인은 림프절 전이인 것으로 알려져 있다. ${ }^{19}$

그러나 갑상선 수질암의 예후와 관련된 인자는 매우 다양 하게 보고되고 있는데 이는 수질암의 발생 빈도가 낮고, 다양 한 임상 경과를 보이며, 생존율과 관련된 예후 인자를 찾기 위 해서는 장기간의 추적관찰이 필요하기 때문으로 생각된다.

\section{REFERENCES}

1) Pacini F, Castagna MG, Cipri C, Schlumberger M. Medullary thyroid carcinoma. Clin Oncol (R Coll Radiol) 2010;22(6):475-85.

2) Machens A, Hofmann C, Hauptmann S, Dralle H. Locoregional recurrence and death from medullary thyroid carcinoma in a contemporaneous series: 5-year results. Eur J Endocrinol 2007;157(1):85-93.

3) Gimm O, Sutter T, Dralle H. Diagnosis and therapy of sporadic and familial medullary thyroid carcinoma. J Cancer Res Clin Oncol 2001; 127(3):156-65.

4) Oh SK, Kim JS. Medullary carcinoma of the thyroid. J Korean Surg Soc 1999;56(1):49-58.

5) Eng C, Clayton D, Schuffenecker I, Lenoir G, Cote G, Gagel RF, et al. The relationship between specific RET proto-oncogene mutations and disease phenotype in multiple endocrine neoplasia type 2. International RET mutation consortium analysis. JAMA 1996;276(19): 1575-9.

6) Sippel RS, Kunnimalaiyaan M, Chen H. Current management of medullary thyroid cancer. Oncologist 2008;13(5):539-47.

7) Hirokawa M, Carney JA, Goellner JR, DeLellis RA, Heffess CS, Katoh $\mathrm{R}$, et al. Observer variation of encapsulated follicular lesions of the thyroid gland. Am J Surg Pathol 2002;26(11):1508-14.

8) Gharib H, McConahey WM, Tiegs RD, Bergstralh EJ, Goellner JR, Grant CS, et al. Medullary thyroid carcinoma: clinicopathologic features and long-term follow-up of 65 patients treated during 1946 through 1970. Mayo Clin Proc 1992;67(10):934-40.

9) Moley JF, DeBenedetti MK. Patterns of nodal metastases in palpable medullary thyroid carcinoma: recommendations for extent of node dissection. Ann Surg 1999;229(6):880-7; discussion 887-8.

10) Scollo C, Baudin E, Travagli JP, Caillou B, Bellon N, Leboulleux S, et al. Rationale for central and bilateral lymph node dissection in sporadic and hereditary medullary thyroid cancer. J Clin Endocrinol Metab 2003;88(5):2070-5.

11) Machens A, Hauptmann S, Dralle H. Increased risk of lymph node metastasis in multifocal hereditary and sporadic medullary thyroid cancer. World J Surg 2007;31(10):1960-5.

12) Cooper DS, Doherty GM, Haugen BR, Kloos RT, Lee SL, Mandel SJ, et al. Revised American Thyroid Association management guidelines for patients with thyroid nodules and differentiated thyroid cancer. Thyroid 2009;19(11):1167-214.

13) Chen H, Roberts JR, Ball DW, Eisele DW, Baylin SB, Udelsman R, et al. Effective long-term palliation of symptomatic, incurable metastatic medullary thyroid cancer by operative resection. Ann Surg 1998;227(6):887-95. 
14) Laure Giraudet A, Al Ghulzan A, Aupérin A, Leboulleux S, Chehboun A, Troalen F, et al. Progression of medullary thyroid carcinoma: assessment with calcitonin and carcinoembryonic antigen doubling times. Eur J Endocrinol 2008;158(2):239-46.

15) Machens A, Schneyer U, Holzhausen HJ, Dralle H. Prospects of remission in medullary thyroid carcinoma according to basal calcitonin level. J Clin Endocrinol Metab 2005;90(4):2029-34.

16) Barbet J, Campion L, Kraeber-Bodéré F, Chatal JF. Prognostic impact of serum calcitonin and carcinoembryonic antigen doublingtimes in patients with medullary thyroid carcinoma. J Clin Endocrinol Metab 2005;90(11):6077-84.

17) Kebebew E, Ituarte PH, Siperstein AE, Duh QY, Clark OH. Medul- lary thyroid carcinoma: clinical characteristics, treatment, prognostic factors, and a comparison of staging systems. Cancer 2000;88(5): 1139-48.

18) Modigliani E, Cohen R, Campos JM, Conte-Devolx B, Maes B, Boneu A, et al. Prognostic factors for survival and for biochemical cure in medullary thyroid carcinoma: results in 899 patients. The GETC Study Group. Groupe d'étude des tumeurs à calcitonine. Clin Endocrinol (Oxf) 1998;48(3):265-73.

19) Dralle H, Scheumann GF, Proye C, Bacourt F, Frilling A, Limbert F, et al. The value of lymph node dissection in hereditary medullary thyroid carcinoma: a retrospective, European, multicentre study. J Intern Med 1995;238(4):357-61. 